This item was submitted to Loughborough's Research Repository by the author.

Items in Figshare are protected by copyright, with all rights reserved, unless otherwise indicated.

\title{
Lifestyle migration in East Asia: integrating ethnographic methodology and practice theory
}

PLEASE CITE THE PUBLISHED VERSION

http://dx.doi.org/10.4135/978144627305013509192

PUBLISHER

(C) SAGE

VERSION

SMUR (Submitted Manuscript Under Review)

\section{PUBLISHER STATEMENT}

This work is made available according to the conditions of the Creative Commons Attribution-NonCommercialNoDerivatives 4.0 International (CC BY-NC-ND 4.0) licence. Full details of this licence are available at: https://creativecommons.org/licenses/by-nc-nd/4.0/

\section{LICENCE}

CC BY-NC-ND 4.0

\section{REPOSITORY RECORD}

O'Reilly, Karen, Rob Stones, and Katherine Botterill. 2019. "Lifestyle Migration in East Asia: Integrating Ethnographic Methodology and Practice Theory”. figshare. https://hdl.handle.net/2134/15699. 


\section{Copy sent to Sage}

\section{Title}

\section{Lifestyle migration in East Asia: integrating ethnographic methodology and practice theory}

\section{Author names and affiliations}

Karen O’Reilly, Loughborough University, UK

Rob Stones, University of Western Sidney, Australia

Kate Botterill, Newcastle University, UK

\section{Metadata}

i. Contributor biographies

Karen O'Reilly is Professor of Sociology at Loughborough University. She has taught ethnographic and qualitative methods for many years around the world including the Essex Summer School in Social Science Data Collection and Analysis, and the Swiss Summer School in Lugano. She has spent 20 years on and off living amongst and learning from British people who move abroad in search of a better way of life. Sociologically this has informed an interest in a broad range of themes, including: ethnicity, identity and community; nations and nationalism; home and belonging; social exclusion; the informal economy; tourism-related migration; and friends and networks. Her interests have more recently turned to practice theories and their implications for ethnographic methodology. Karen is author of Ethnographic Methods (Routledge), Key Concepts in Ethnography (Sage), International Migration and Social Theory (Palgrave), and co-editor of Lifestyle Migration: Expectations, Aspirations and Experiences (Ashgate). She has her own personal web page, and an institutional web page. 
Rob Stones is Professor of Sociology in the School of Social Sciences and Psychology at the University of Western Sydney. His books include Sociological Reasoning (1996) and Structuration Theory (2005). He continues to develop strong structuration theory, and its use in case study research in a range of different substantive fields. He is currently completing Why Current Affairs Needs Social Theory, which will be published by Bloomsbury Academic (2014). A third edition of his edited volume Key Sociological Thinkers ( $2^{\text {nd }}$ edition 2008) will be published in 2015. Recent articles and chapters include: 'Social Theory and Current Affairs: A Framework for Greater Intellectual Engagement’, British Journal of Sociology, (2013); 'Strengths and Limitations of Luc Boltanski’s On Critique', in Simon Susen and Bryan S. Turner (eds) The Legacy of Luc Boltanski, London: Anthem Press, (2013); 'Social Theory, Current Affairs, and Thailand’s Political Turmoil: Seeing Beyond Reds vs. Yellows’ (with Ake Tangsupvattana), Journal of Power (2012); ‘Theorising Big IT Programmes in Healthcare: Strong Structuration Theory Meets Actor Network Theory’ (with Trish Greenhalgh), Social Science and Medicine (2010). He is the editor of two book series for Palgrave Macmillan, Traditions in Social Theory and Themes in Social Theory. Kate Botterill is a Postdoctoral Research Associate in the School of Geography, Politics and Sociology at Newcastle University, UK. She currently works on an inter-disciplinary AHRCfunded project on 'Young people’s Everyday Geopolitics in Scotland', with colleagues at Edinburgh University and the University of St Andrews. The project explores how religious and ethnic minority young people understand and negotiate global, national and local political events and discourse. She has over 10 years experience as a qualitative researcher with expertise in the areas of migration, mobility and social justice and has worked in policy and academic research for a number of different organisations. In addition to her recent work at Loughborough University on the ESRC ‘Lifestyle Migration in East Asia’ project, she completed a doctorate at Newcastle University on post-accession Polish migration to the UK, 
exploring the differential mobilities of young Polish migrants in Edinburgh and Krakow and the role of social forms, such as the family and community, in the migration process. She is currently developing publications from these works, including a forthcoming article in Sociology on 'Family and Mobility in Second Modernity: Polish Migrant Narratives of Individualization and Family Life’. Personal Web:

http://newcastle.academia.edu/KatherineBotterill

ii. Relevant disciplines: Sociology, human geography, politics, social anthropology, cultural studies, social psychology, communication studies

iii. Academic Level: third year undergraduate and post-graduate social science students and above.

iv. Methods used.

- Ethnographic methodology

- Analysis of existing literature and data (offline and online)

- Analysis of theoretical and empirical literature

- Analysis of weblogs and online forums

- The study of expatriate organizations and magazines

- $\quad$ Face to face, telephone and skype interviews

- Life history and semi-structured interviews

- An online quantitative survey, including a few qualitative responses

- Autophotography

- Participant observation

v. Keywords: practice, structuration, ethnography, narrative, life history, migration

vi. Links The project blog

\section{Abstract}


This project was designed to study the lifestyle migration of British migrants in Thailand and Malaysia and Hong Kong Chinese migrants to mainland China. With a focus on the meanings, motivations and outcomes of lifestyle migration in Asian contexts, the goal was to tell practice stories. Practice stories explain a phenomenon by describing how it develops over time as norms, rules, and organizational arrangements are acted on and adapted by individuals as part of their daily lives, in the context of their communities, groups, networks, and families. This paper provides an explanation of the research project and its initial aims; describes what is meant by practice stories, and indicates their role in the design of the research; considers how practice stories emerge from a bringing together of strong structuration theory, the concerns of the lifestyle migration literature, methods, and empirical data; discusses the fieldwork undertaken by the authors in Malaysia and Thailand, and thus, illustrates how a project underpinned by ethnographic methodology and practice theories can address the initial aims of the research project.

\section{Learning Outcomes}

- Learn the basic principles of strong structuration theory

- Critically analyse the relationship between social theory and social research methods

- Understand what is meant by practice stories, and critically evaluate their role in the design of social research

- Understand how practice stories emerge from a bringing together of strong structuration theory, the concerns of substantive literature, methods, and empirical data

\section{The main body of the case}

\section{Introduction}


This project was designed to study the lifestyle migration of British migrants in Thailand and Malaysia and Hong Kong Chinese migrants to mainland China. The initial focus was on investigating the meanings, motivations and experiences of the migrants, and also on the migration 'outcomes', which refers both to the character of the migrants' lives within the destination location and the effects this migration has on those destination localities themselves. We designed our research orientation to these goals from the outset on the basis of a meta-theoretical framework based on the approach of strong structuration theory, which is a synthesis of key insights into the core sociological concepts of structure and agency, and is expressly formulated to be used in empirical research (Stones, 2005). The principle was to use the richness and conceptual refinements of contemporary social theory to guide our research, and to be self-conscious about the ways in which theory, methods and empirical data affected one another in the course of the research process. We used a diverse range of ethnographically-informed research methods, including narrative interviews, participant observation, social media analysis, and survey methods. Our ultimate goal was to tell what O’Reilly (2012b) has termed 'practice stories’ about migration. This paper will:

1) provide an explanation of the research project and its initial aims.

2) describe what is meant by practice stories, and indicate their role in the design of the research.

3) consider how practice stories emerge from a bringing together of strong structuration theory, the concerns of the lifestyle migration literature, methods, and empirical data.

4) discuss the fieldwork undertaken by the authors in Malaysia and Thailand, and thus, 5) illustrate how a project that is methodologically designed from the outset can guide the unveiling of practice stories that address the initial aims of the research project. 


\section{The Project and its Aims: Lifestyle Migration in East Asia}

Lifestyle migration is spatial mobility undertaken more for quality of life reasons than for economic enhancement or security. Although much migration is motivated by the desire for a better quality of life, nevertheless the term lifestyle is being used by migration scholars to distinguish relatively affluent migrants moving full or part-time, temporarily or permanently, to places that are economically less developed in order to benefit from a lower cost of living, a raised status, and often better climate and health conditions, and an improved physical (and perhaps social) environment (Benson and O’Reilly 2009). Lifestyle migrants include international retirement migrants (Casado-Díaz 2006; Helset et al. 2005; King et al. 2000; Rodríguez et al. 2005), second home owners (Hall and Müller 2004); counterurban-ites (Buller and Hoggart 1994); and residential tourists (McWatters 2008; Mantecón 2008), among others. They go to diverse destinations, including France, Spain, Panama, Morocco, Malaysia, Mexico, and Costa Rica. As such their flows are often counter to many traditionally conceived labour migration flows. However, much of the existing literature on lifestyle migration has researched Western contexts. The nature and outcomes of lifestyle migration in Asian contexts is still little understood. Our study of Lifestyle Migration in East Asia was thus designed to address this empirical gap, and to approach the design of the research in a theoretically self-conscious manner. We chose to study British in Malaysia and Thailand because they have been identified as important destinations experiencing profound effects (Sriskandarajah and Drew 2006); and our partners examined Hong Kong Chinese in China since they offer such a fascinating comparison with unknown dimensions.

Re-thinking migration from a perspective inclusive of both East Asia and the West prompts us to pose a number of questions. What might lifestyle migration mean in societies that do 
not share the same cultural understandings of 'a good life'? How do people make sense of and re-negotiate their work-life balance and freedom from prior constraints? How is lifestyle being transformed where cultural understandings of leisure and consumption differ? What effects are globalization and flexible citizenship having on men and women's everyday lives and selves in the east and the west, and how far are these similar or different? How are local specificities manifested in lifestyle migrants' understandings of leisure and work? What is the role of technology in the creation and maintenance of transnational lifestyles?

In investigating the character of the migrants' lives and social relationships once they had arrived in the destination location we asked questions such as the following. Do lifestyle migrants encourage others to move? What networks have they established, where? Are some people the nodal points of networks? Do community leaders emerge? Have different attitudes emerged, and different social structures? Do different statuses of migrants and lifestyle migrants emerge? And then in looking at the effects that lifestyle migration has on destination localities, we were guided by a further set of questions. Are there consumption demands from the lifestyle migrants that affect the social structure of the locality? We found, for example, that the lifestyle migration of westerners to Hua Hin in Thailand, a coastal town 130 kilometres south on Bangkok on the Kra Isthmus, led, in turn, to internal migration from the Northeast of Thailand to Hua Hin to work in all kinds of menial jobs -as guards and gardeners, in maintenance, as nurses for the elderly, and in massage and bar work. What is the impact on local healthcare and education provision and on property prices? Does this create any tensions?

\section{Practice Stories in Context}


This is a very broad and apparently eclectic set of research questions. However, as noted, the goal of our project was to tell practice stories about British migration in Malaysia and Thailand. The idea of 'practice stories’ was formulated by Karen O’Reilly as a way of drawing attention to the chronological, narrative, nature of the structuration process, at the same time as to structuration theory's emphasis on the centrality of practices. To emphasize this latter point in her book International Migration and Social Theory, O’Reilly quotes the American theorist Ira J. Cohen who explains practices are:

synonymous with the constitution of social life, i.e. the manner in which all aspects, elements and dimensions of social life, from instances of conduct in themselves to the most complicated and extensive types of collectivities, are generated in and through the performance of social conduct, the consequences which ensue, and the social relations which are thereby established and maintained (Cohen, 1989: 12, original italics; quoted in O’Reilly, 2012b: 14).

Practice stories explain a phenomenon such as lifestyle migration by describing how it develops over time as norms, rules, and organizational arrangements are acted on and adapted by individuals as part of their daily lives, in the context of their communities, groups, networks, and families. This emphasis on the social 'context' of the practices is important, as it draws attention to the socio-structural terrain within which the practices of any individual or collective is enacted. Thus, it is important to always think of practice stories as happening within a structural terrain, a configuration, that will include constraints and opportunities, inequalities and hierarchies of many kinds, and which will also continually exert an influence on the internal lives of the people within it. Practice stories direct us to investigate ongoing processes and the contexts that make them possible, such as with the initial decision to 
migrate, and then also to follow these narratives through as the initial practices then go on to shape general patterns, arrangements, rules, norms, and other structures in the destination locales. In doing so they put people's actions in the context of their historical and contemporary conditions.

Disciplined epistemology requires that research goals are differentiated from each other, and so it was important in our research design to be able to distinguish one practice story from another. There is a difference, for example, between the aspects of the world that will be brought into focus when aiming to research the practice story leading to the moment of migration, and those brought into focus when aiming to research the nature of lifestyle migrants’ current social relations after several years in their destination communities. Likewise, investigating the practice story relevant to a concern with the effects on the social structure of the destination locality will be different again. Although each of these practice stories can be linked to the others, in terms of genealogy or causal effect, for example, the research focus and aims they represent are clearly distinguishable. Designing the research around strong structuration and practice stories in relation to specific research aims, and subquestions within these, meant that we had a strong guiding framework for fieldwork.

\section{Strong Structuration and its Background}

Practice stories, as we have noted, are grounded in structuration theory or practice theory. These theories have been developed as a synthesis of thought developed around the questions and problems that have preoccupied social thinkers over many decades. At the heart of a great deal of sociological theory is what we might term an agency/structure dualism; that is, a tendency to perceive the agency of individual human actors as distinct and separate from 
social structures. In early sociology, much of the emphasis was on structures and how they pressured, constrained and moulded social behaviour. In the work of Durkheim, for example, 'social facts' such as laws, religion, education, and pervasive aspects such as norms, were depicted as having a force of their own on societies, independently of individuals and their actions. In Marx’s work, socio-economic forces were often presented as working independently to shape human societies. This approach was gradually challenged by a variety of schools of thought which placed much more emphasis on subjectivity and agency. These included symbolic interactionism, ethnomethodology, phenomenological sociology, social constructionism, and hermeneutics. These approaches emphasised the creative, reflexive and dynamic aspects of social life. They particularly emphasized the complex interpretive capacities of humans as actors, distinguishing these from the capacities of non-human animals, and from the typically re-active nature of objects in the natural world. Sociology has now reached something of a consensus, in which it is impossible to ignore all that has been learned on either side and scholars have sought ways to understand the ongoing interaction of structure and agency. These approaches tend to be called structuration or practice theories.

Structuration theory is a social theory of practice proposed by Anthony Giddens (1976, 1979, 1984). Giddens insists that social life is neither solely the outcome of individual actions (determined only by how individuals feel, what they intend, or plan to achieve) nor entirely determined by social structures (the institutional context of authority and power, economic resources, norms and cultural expectations, which Giddens summarizes as the context of 'rules and resources'). Instead, social structures limit what people can and cannot do, and even what they try to or wish to do. But individual and collective actors do have degrees of autonomy and capacities to resist, and to make their own judgements and decisions, and so on, within various limits; and the very social structures that set the limits of possible 
behaviour are made and remade by individuals in the process of exerting their agency. For Giddens, therefore, for many purposes we should not even think of agency and structure as (ontologically) distinct; they are a duality - always interdependent and interrelated. Against structural determinism, Giddens particularly emphasized the knowledgeability actors have of their structural conditions of action, and the ways they skilfully draw on this knowledgeability when they engage in practices.

In developing strong structuration theory, Rob Stones (2005) draws attention to this aspect of Giddens's work in writing about the situational knowledge that actors have about the terrain of action that faces them at a given time. He combines this with a more developed attention to the nature of this structural terrain and its various networks, relationships, hierarchies of power and resource distributions. In shorthand, Stones refers to such configurations as 'external structures', and is clear that it is often important to analytically separate out the external structural terrain for independent investigation (see Archer, 1995; Stones, 2001). Amongst other things, this allows the researcher to move between the knowledgeability a lay actor - a lifestyle migrant, for example -may have of the structural terrain and the researcher's own grasp of the conjuncture. Stones refers to this as situational-specific or conjuncturally-specific knowledge and, like the other concepts we employ, it can guide the search for empirical evidence. He refers to it as one form of 'internal' or 'internalized' structure, so as to insist on the close relation between the external social world and the internal world of the actors who inhabit that world. This is a close relation but the complex nature of actors means that one should never assume, a priori, that external and internal structures are identical. 
Pierre Bourdieu (1977, 1984, 1985, 1990), like Giddens, also proposed the concept of practice as a way of thinking about social processes; that is, the making and acting out of daily life. However, Bourdieu’s primary emphasis was on another aspect of actors’ character and capabilities. His notion of the practice of social life draws on the concept of habitus. Habitus refers to the enduring dispositions, habits, ways of doing, ways of thinking, and ways of seeing the world that individuals acquire, singly and in groups, as they travel through life. These are, therefore, structures that have become embodied within people, and are then acted out by them, often without thought, as 'second nature'. Bourdieu argued that people's tastes and preferences, choices, desires and actions cannot be separated from the structural constraints and influences of culture, class, gender and so on. This is because people internalize ways of responding to the world from their surroundings, and this extends to their ideas of what it is possible for them to achieve. Much of this happens below the level of reflective consciousness, in what Bourdieu treats as a 'taken for granted' manner. People are always in practical relations to the world and practices (what we do), tend to be reasonable (sensible, plausible) adjustments to immanent tasks and to the future rather than, as some people see them, rational calculations or plans entirely thought through in advance. The skills and knowledge entailed in habitus are less about the immediate structural terrain, as skills and knowledgeability tend to be for Giddens, and more about enduring, transposable capacities such as the ability to cook, to teach, to play music, to chair a meeting, to act, to perform well in a sport, to write a speech, and so on - that need to be adapted to particular circumstances. Bourdieu has less to say about the particular circumstances and more to say about the inherited, transposable, dispositions. Stones integrates this dimension of agency into strong structuration, sometimes using Bourdieu's own term, habitus, and at others speaking about 'general dispositions'. He thus emphasises the 'general' nature of these dispositions, indicating that they are not tied down to, or expressly related to, any specific situation, but 
have to adapt to its contingencies. Stones also goes out of his way to stress the point that cultural and imaginative discourses and ethical principles are also durable and transposable, and need to be included within habitus.

By combining the emphases of both Giddens and Bourdieu, strong structuration theory is able to look at how the two - situational knowledge and habitus - combine dynamically in producing action. For example, at the point of thinking about their future migration, lifestyle migrants will combine many aspects of engrained habitus with newly acquired 'situational' information about the place they are considering moving to. Their habitus will also, for example, be more or less individualistic and more or less community oriented - more or less tied to family, friends and locality. Strong structuration also includes a space for the 'active agency’ that individuals and collectives can employ, giving them the capacity to react back on both forms of internal structure in various ways (see Stones, 2005: 100-109).In developing the notion of practice stories, Karen O’Reilly draws attention to each of these various aspects of the strong structuration model but also makes much of the important methodological point that whilst it would be possible to just employ any one concept from strong structuration as a guide to empirical research, practice stories will inevitably be larger than this, and so will combine the concepts from strong structuration to varying degrees and in larger and smaller doses depending upon the story being investigated (O’Reilly, 2012b: 33-4).In her own work, and in the current study, she has also drawn on further insights from, firstly, Mustafa Emirbayer and Ann Mische (1998) on the role that actors' imaginative orientation to the future plays within their 'active agency’, and, secondly, from Jean Lave and Etienne Wenger's (1991, Wenger 1998), description of communities of practice and situated learning. 
The guiding concept of 'communities of practice', which refers to any social group, or cultural community (family, community, work mates, social club, a partnership) that comes together and has to work out how to get on together, is clearly useful in the current research when it comes to the practice story of settlement, the point at which lifestyle migrants begin the process of finding a way to live in their new surroundings, but with a habitus brought from elsewhere . By observing social life through a community of practice it is possible to think through the dynamic between immanent structural fields, including formal and informal rules, regulations and laws, on the one hand, and individual will and choices, on the other. It is in their communities of practice that individuals learn what the rules of 'the game' are within the new structural terrain, how much they have to stick to them, and how much can be 'negotiated'. And it is from our interactions with people that we form ideas about how things might be different, and who has the power to change what. Lave and Wenger (1991) call this 'situated learning' and one can see clearly how this links in to the idea of a structural terrain.

\section{Research Methods for Practice Stories}

These theoretical perspectives are a guide to thinking about how lifestyle migration - and processes related to it -unfolds in practice. Methodologically, this almost always involves conceptualising and learning about the wider external structures that frame the practice of a given community or group. This can be achieved via the combination of theoretical perspectives, documentary analysis, and learning practically about the smaller, local, relevant context. Ethnography that pays attention to both wider structures and the thoughts and feelings of individuals, within the context of action is an ideal approach to research practice, and is the approach we have followed in the present research project. On the other hand, the ethnographic method - as would be the case for any chosen method - needs to be consciously 
adapted to the concepts at work within the theoretical approach. Thus, Willis and Trondman (2000: 5) explain the principles of ethnography as follows:

“...a methodology that draws on a family of methods involving direct and sustained social contact with agents, and on richly writing up the encounter, respecting, recording, representing, at least partly in its own terms, the irreducibility of human experience”.

The understanding and representation of experience is crucial here. Researchers who do ethnography seek to explain the culture in which experience is located, but also acknowledge that 'experience is entrained in the flow of history' (Willis and Trondman 2000: 6). The emphasis placed by our approach on being able to specify the characteristics of the structural context of action, and in addition to think about human perceptions and knowledgeability in relation to this, to think about previous influences on the formation of those perspectives (habitus), and to construct our practice stories in situ and over time, provides much more conceptual flesh on the bones of 'the flow of history'. The approach thus provides a good deal of additional guidance and direction for the creative use of ethnographic methods. O’Reilly (2012a) has also taken Willis and Trondman's argument further by arguing that ethnography itself is a practice that evolves in design as the study progresses and that it should be overtly informed by a theory of practice.

In our research we did not have the funds or the time to do a full ethnographic investigation. Traditionally, ethnography takes a year or more and involves immersing oneself in the context. We had strict limitations on our research fieldwork with funding for just over three weeks in each country. However, we were keen to engage with the principles of ethnography 
and develop flexible ways of immersing ourselves in the context. From the start of the project in February 2012 Karen and Kate both started to familiarise themselves with their destinations and drew on a diverse array of ethnographically-informed methods to do this.

The first thing they did was consult existing literature, web sites, documents, statistical data, and anything else they could lay their hands on to learn about the historical relationship between Thailand/Malaysia and the UK. Practice stories require an understanding of external structures, both in the form of relevant wider, historical and social trends and forces, and also more 'proximate' external structures (see O’Reilly, 2012b: 24) that most directly constitute the conditions encountered by the people being researched, and which shape their current practices, norms and habits. Developing such a mapping also means grasping relevant constraints and opportunities in the shape of policies and trends. To build up a picture of this structural terrain faced by migrants the research team studied the social, political and economic (and to a lesser extent the geographical) situation in each country, especially in relation to migration and the West. We read empirical and theoretical studies on colonialism and post-colonialism, and theoretical arguments about neo-liberalism and globalisation. We studied other types of migration such as corporate expatriates, and lifestyle migrants in other parts of the world. Our central goal, informed by practice theory, was to begin to understand how these practices and configurations shape behaviours and attitudes today, perhaps externally through policies and legal arrangements, and perhaps internally via norms, habits, expectations and attitudes.

It was also necessary to understand the various laws, policies and economic constraints that a specific migrant moving to Malaysia or Thailand faces, such as the availability of housing and pensions. We wondered what the rationale is behind certain policies to attract foreigners 
as residents (where this is the case). Does this tend to privilege some kinds of migrant over others, and where do lifestyle migrants fit into the hierarchy of those targeted? To address such questions we read documents, but we also undertook interviews with experts, such as consular and embassy officials. And we learned quite a bit from our interviews with migrants and the social media analysis of online forums.

Having started to understand the wider, upper level and more proximate external structures (O’Reilly, 2012b: 24, 149-50) framing and shaping lifestyle migration, a further goal was to begin to understand the habitus and dispositions of the migrants themselves, that is the internalised structures that shape how they behave and that, in turn, are shaped by their experiences of having migrated. It was also important to understand the new communities of practice within which migrants acted, made decisions, and which constantly shaped their actions and desires. This involved placing people's habits and behaviours in the context of the rules and norms and expectations of those around them. The main way in which we were able to interpret the ways in which migrants had internalised their new situational structures was through conducting and recording in-depth, face-to-face interviews, participant observation. We supplemented this information with an online survey. These and other methods, discussed in more detail below, combined with critical reflection on our findings using sociological insights, provided the material with which to begin to tell practice stories about aspects of the migration process for these cases.

\section{Our fieldwork in Malaysia and Thailand}

During the pre-fieldwork phase, we designed an online survey for lifestyle migrants living in Thailand and Malaysia. The survey was distributed to expatriate organisations and to individual contacts and the sample was achieved through simple snowball techniques. The survey was 'live’ through April to November 2012, and obtained 112 responses (57 from 
Malaysia, 54 from Thailand, and one who did not specify where he lived). Using the survey we were able to gather interesting demographic information. We also asked about their migration histories, social lives, social networks and uses of technology for maintaining social ties, their personal values and goals, and their relationships with other ethnic groups. Some of the results can be viewed on our web site. We understand this survey as contributing to the task of immersing oneself in the context - a key principle of ethnographic work.

The fieldwork in Malaysia and Thailand then took place between July and November 2012 during which time we undertook a total of 65 interviews (Malaysia: 31; Thailand: 34). We used a variety of interview methods, including face-to-face, email, skype and telephone interviewing (see table 1 for a breakdown). Most of the interviews were conducted with British lifestyle migrants in Penang, Malaysia and in Hua Hin, Thailand. The rest were conducted through digital channels with respondents in other parts of Thailand and Malaysia. These included 'expert' interviews with consular staff and migration intermediaries, such as property developers and 'expat' magazine publishers.

\begin{tabular}{|l|l|l|l|l|}
\hline Interview Type & \multicolumn{2}{|c|}{ Malaysia } & \multicolumn{2}{c|}{ Thailand } \\
\hline & Recorded & Unrecorded & Recorded & Unrecorded \\
\hline Face to face interviews & 15 & 5 & 25 & 1 \\
\hline Email interviews & 4 & 0 & 8 & 0 \\
\hline Skype interviews & 5 & 0 & 0 & 0 \\
\hline Telephone Interviews & 1 & 1 & 0 & 1 \\
\hline Total & & 31 & 34 & 3 \\
\hline
\end{tabular}

Table 1: Breakdown of interviews conducted by type 
Much of our understanding about the initial and evolving 'habitus' of lifestyle migration, and the ways in which this interlaced with new situational knowledge and active agency, came from in-depth interviews with migrants themselves. We asked migrants to describe their motivations for moving, their experiences of getting visas, settling in, staying in touch with family and friends, and making new friends. We asked them about their work and social lives in Malaysia and Thailand, and their plans for the future. However, goals, desires, and habits are often both intuitive and creative and are not easily accessed through interviews. Our study also benefitted therefore, from participant observation. Whilst doing interviews with respondents, we spent three weeks in Penang and Hua Hin, respectively, attending events, and talking to people in public places and private homes (Karen in Malaysia, Kate in Thailand). We monitored different online forums during the period July to November, watching what was being said, noting the topics that arose and how things were discussed. We also analysed the content of several expatriate magazines, and the membership and ethos and activities of many different organisations (eg. St Patrick’s Society of Selangor; International Women's Association, Penang), and the content of migrants' weblogs about life in East Asia. A final method we used was auto-photography which involved asking respondents to send us their own photos of life in Penang and Hua Hin. We received 27 photographs from respondents in Malaysia and Thailand and were directed to many others that migrants had posted themselves on personal weblogs.

\section{Conclusion}

To conclude, this project has employed a diverse array of methods in order to achieve Clifford Marcus' (2012: p.xiv) goal of both living ‘inside a culture’ and acquiring a 'rich, critically developed context for interpretation' within the financial and time limitations of the funded project. 
The project was underpinned by a theoretical framework informed by strong structuration theory (Stones 2005), and the goal was to tell practice stories (O’Reilly 2012b); that is to describe some of the processes involved in lifestyle migration in East Asia in such a way as to respect the creative and processual nature of social life and to reveal the structuration processes involved as social life unfolds. This paper has been more at pains to describe this theoretical framework and how it informed our methodology and selection of methods than to describe the actual research methods in more detail. This is because we believe this is the unique aspect of this project. The practice stories we have begun to tell will have to wait for a different publication, but in the meantime readers can keep up to date by consulting the project web site.

\section{Discussion questions}

- What are structuration theory, practice theory and strong structuration theory?

- What is the relationship between ethnographic methodology and ethnographic methods?

- How can we understand the role of practice stories in social research?

- What sorts of methods can be used to understand a phenomenon as a social process?

- How do diverse sets of methods fit together to make a coherent methodology in a research project?

- Exercise: Consider the various strong structuration and practice theory concepts outlined in the paper in relation to specific experiences in the field. How might the discipline, creativity and guidance afforded by the concepts be reconciled with experiences in the field?

\section{Further readings}

Stones, R., 2005. Structuration theory. Basingstoke: Palgrave Macmillan.

Willis, P. and Trondman, M. 2000. Manifesto for Ethnography, Ethnography 1(1): 5-16 
O’Reilly, K. 2009. Key Concepts in Ethnography. London: Sage

O’Reilly, K. 2012a. Ethnographic Methods. $2^{\text {nd }}$ ed. London: Routledge

O’Reilly, K. 2012b. International Migration and Social Theory, London: Routledge

\section{References cited in the text}

Archer, M. 1995. Realist Social Theory: A Morphogenetic Approach, Cambridge: Cambridge University Press.

Benson, M. and O'Reilly, K., eds, 2009. Lifestyle migration : expectations, aspirations and experiences. Farnham: Ashgate.

Bourdieu, P. 1993. 'Concluding Remarks: For a sociogenetic understanding of intellectual works’, in C. Calhoun, E. Li Puma and M. Postone (eds),Bourdieu: Critical Perspectives. Chicago: University of Chicago Press, pp. 263-75

Bourdieu, P., 1977. Outline of a theory of practice. Cambridge: Cambridge University Press.

Bourdieu, P., 1984. Distinction : a social critique of the judgement of taste. London:

Routledge \&Kegan Paul.

Bourdieu, P., 1985. The Social Space and the Genesis of Groups. Theory and Society, 14(6), 723-744.

Bourdieu, P., 1990. The logic of practice. Cambridge: Polity.

Buller, H., and Hoggart, K., (1994), International Counterurbanisation, Aldershot: Ashgate.

Casado Diaz, M.A., 2006. Retiring to Spain: An Analysis of Differences among North European Nationals. Journal of Ethnic and Migration Studies, 32(8), 1321-1339.

Cohen, I.J., 1989. Structuration theory : Anthony Giddens and the constitution of social life. Basingstoke: Macmillan. 
Cohen, I.J., 1989. Structuration theory : Anthony Giddens and the constitution of social life. Basingstoke: Macmillan.

Emirbayer, M. and Mische, A., 1998. What Is Agency? American Journal of Sociology, 103(4), 962-1023.

Giddens, A., 1976. New rules of sociological method : a positive critique of interpretative sociologies. London: Hutchinson.

Giddens, A., 1979. Central problems in social theory : action, structure and contradiction in social analysis. London: Macmillan.

Giddens, A., 1984. The constitution of society : outline of the theory of structuration. Cambridge: Polity.

Hall, C. and Müller, D., (2004) 'Introduction: second homes, curse or blessing? Revisited', in C. Hall and D. Müller (eds.) Tourism, mobility and second homes: between elite landscape and common ground, Clevedon: Channel View Publications.

Helset, A., Lauvli, M. and Sandlie, H., (2005) ‘Jubilados Noruegos en España’, in Rodríguez et al. pp.167-194.

King, R., Warnes, T. and Williams, A., 2000. Sunset lives : British retirement migration to the Mediterranean. Oxford: Berg.

Lave, J. and Wenger, E., 1991. Situated learning : legitimate peripheral participation. Cambridge: Cambridge University Press.

Mantecon, A., 2008. The Experience of Tourism: A Sociological Study of the Process of Residential Tourism. Barcelona: Icaria. 
Marcus, G. 2012. 'Foreword’, in Boellstorff, T., Nardi, B. Pearce, C. and Taylor, T.L. 2012, Ethnography and Virtual Worlds. A Handbook of Method. Princeton: Princeton University Press, pp. xiii-xvii

McWatters, M. 2008. Residential Tourism: (De)Constructing Paradise. Bristol: Channel View Publications.

O’Reilly, K. 2012a. Ethnographic Methods. $2^{\text {nd }}$ ed. London: Routledge

O’Reilly, K. 2012b. International Migration and Social Theory, London: Routledge

Rodríguez, V., Casado Díaz, M. and Huber, A. 2005. (eds) La Migración de Europeos Retirados en España, CSIC, Madrid.

Sriskandarajah, D. and Drew, C. 2006. Brits Abroad - Mapping the scale and nature of British emigration, London: IPPR.

Stones, R., 2005. Structuration theory. Basingstoke: Palgrave Macmillan.

Stones, Rob., 2001. 'Refusing the Realism-Structuration Divide', European Journal of Social Theory vol. 4 no. 2 pp. 177-197. Reprinted in O’Donnell, M. (ed.) Structure and Agency [Sage Key Debates in Sociology] (London: Sage, 2010).

Wenger, E., 1998. Communities of practice : learning, meaning, and identity. Cambridge: Cambridge University Press.

Willis, P. and Trondman, M. 2000. Manifesto for Ethnography, Ethnography 1(1): 5-16 